Aimée Moutet's study of "Problèmes humains de la rationalisation et action ouvrière sous le gouvernement de Front populaire 1936-1938" was particularly memorable for placing the issue of factory personnel management in the context of economic crisis, industrial militancy (the strikes of 1936), and stricter surveillance of work time and productivity.

Finally, the conference should be praised for its own technique sociale, a strict adherence to the humane organizational principle of distributing the numerous and lengthy papers to all participants well in advance, and for restricting presentations to fifteen-minute summaries. This allowed for sufficient discussion of the individual papers, and for a significant reduction of the fatigue quotient of the audience.

\title{
Western Society for French History
}

\author{
W. Scott Haine \\ The American University
}

The October 1989 meeting of the Western Society for French History included two sessions and several individual papers on working-class history, covering such diverse subjects as immigration, neighborhood solidarities, municipal socialism, women's work, and popular culture.

On the thirtieth anniversary of its publication, Barrie M. Ratcliffe (Université Laval), offered a systematic critique of Louis Chevalier's classic in his essay "Classes laborieuses et classes dangereuses à Paris pendant la première moitié du XIXe siècle? The Chevalier Thesis Reexamined." While recognizing the richness of Chevalier's images, especially in his references to the "pathological" city and his attempt to evoke the "lived experience" of urban life, Ratcliffe argued that the data does not support the argument. The direct connection that Chevalier drew between immigration and crime has been seriously questioned for a number of years. The theory of urban alienation in a "strange" environment has been undermined by urban historians of Paris and other cities who have shown that, even in poverty, urbanites find ways to forge solidarities. The fundamental question Ratcliffe's critique raises is, What dominant metaphor can replace "laboring classes and dangerous classes?"

Christine Piette (Université Laval) in her "Immigration et pauvreté à Paris pendant le première moitié du XIXe siècle" used a hitherto underutilized source, the admission registers to Parisian hospitals, to argue that the link between immigration and poverty was very strong. She found that a very high proportion of hospitalized Parisians ( 76 percent in 1820 and 80 percent in 1850) were born outside of Paris. Piette admitted that these figures are almost certainly an overrepresentation -hospitals in this era still tended to be the preserve of the lower 
classes - but her chief concern was, by how much? Her tentative conclusion was that the proportion was less than 80 percent but probably much higher than the figure of 50 percent cited by Bertillon in his classic turn-of-the-century study, which she felt underrepresented the working class. Her conclusion, intriguing, but as she admitted, still largely unsubstantiated, was that during the first half of the nineteenth century Paris had a much higher immigrant population than historians have realized.

Raymond Jonas (University of Washington), in his paper "A Barrier Against the Rural Exodus? The Textile Industry and Working Housholds in the Isère in the Nineteenth Century," answered his question in the affirmative. Using the department's data on demographic contour maps, he argued that the rural textile industry served two vital functions: first, it operated as a "regional safety net" catching the "floating population" of the countryside; second, it "prepared, even initiated, the transition from peasant to urban worker." This transition was facilitated by the expansion of the Lyon silk industry into the outlying rural area. Jonas's work thus helps illuminate the spatial dynamics of working-class formation in the southeastern region between some of France's most important industrial cities, Lyon, St . Etienne, and Grenoble. However, the manner in which the gradual transition from country to city affected the mentality and behavior of workers still needs to be explored.

The panel "Quarter and Community in French Cities of the Nineteenth and Twenieth Centuries" took an opposite approach to the papers on immigration and primarily examined the social and psychological dynamics of urban proletarians. George Sheridan, Jr. (University of Oregon) examined "Solidarities and Neighborhoods: The Case of the Silk Weavers of Lyon, 1830-1880." He investigated two proletarian neighborhoods, Brotteaux-Guillotière and Croix-Rousse, in an attempt to discover the manner in which workers used space and sociability to forge their associational and political life. His rich and detailed social and geographic perspective defies simple summation. In short, he noted three relations between what he terms "solidarity and place." First, a "reciprocal relationship" could develop between neighborhood groups, which would function as "building blocks" in a citywide organization. The second relationship covered "quasiautonomous" gatherings, which were sometimes organized around a central committee or charismatic individual, usually in response to a crisis situation. The third was less a relationship than "an affirmation of localism in a nearly pure and absolute fashion," typified by the dense concentration of consumer cooperatives. Although all three forms were evident in both neighborhoods, the Croix-Rousse displayed more formal and disciplined activity and structure, while the BrotteauxGuillotière showed greater dynamism and spontaneity in small groups and associations. Sheridan's combination of specific historical detail with a sociological flair for classification made this an extremely fruitful paper whose typology could be applied to other cities. However, he should have tied it more fully to Lyon's political history or to the evolution of the working-class movement. 
Mark Trauggot (University of California, Santa Cruz), in "Neighborhoods in Insurrection: The Parisian Quartier in the February Revolution of 1848," utilized archival sources and the writings of August Blanqui to examine barricade construction in Blanqui's beloved Saint-Merri district in 1830 and 1848. Reviewing the vital statistics of 1848 insurgents who applied for government assistance for losses suffered in the fighting, he found that the overwhelming majority (73 percent) were immigrants who fought on barricades within a three-block radius of their homes. Auguste Blanqui carefully chose a right-bank working-class district (Saint-Merri) for the site of his abortive revolution in 1839. In 1868 or 1869 , released from prison and in Brussels, he drafted a treatise, "Concerning Barricades," which distilled his past experience and advice for future barricade fighters. Based in part upon Blanqui's critique, Trauggot pinpointed tensions in barricade fighting between localism and centralism and between spontaneity and organization. Combat on the cobblestones often lacked direction and coordination, and for these reasons revolutionaries tried, with little effectiveness, to adopt the cosmopolitan strategy. However, the link between the barricade and the neighborhood was too strong to be easily put asunder. Trauggot's ingenious analysis should be expanded to include the barricades of the Paris Commune.

In "Searching for Parisian Neighborhood Life: Infractions, Insults, Anecdotes, Invitations, and Inverviews," W. Scott Haine (The American University) examined working-class neighborhood dynamics between the crushing of the Paris Commune and the Great War (1914). Despite more than half a century of heavy immigration (1820-70) and two decades (1850-70) of massive urban renewal (Haussmanization), Parisian workers still retained a sharp sense of neighborhood. However, this sense of place had subtly shifted from the streets to the shops and from a public sense of solidarity on the barricades to a private sense of solidarity in cafés and other shops. Courtroom testimony and newspaper accounts reveal that, through the politics of neighborhood privacy, workers after 1871 tried to define their apartments, courtyards, and shops as private spaces, outside the legitimate surveillance of the police and other government agents. Although the outlines of these strategies have been sketched, more detailed research is needed to answer the larger questions of how these tactics evolved over time and to what degree they varied between the different Parisian districts.

David Wright (College Misericordia), in his paper "Socialist Party Leadership in Limoges During World War I and the Post-War Years," lent support to this notion of a politics of neighborhood privacy. Although he dealt mainly with politicians and programs rather than with workers and their neighborhoods, his paper illuminated the antimilitarist strategies of socialist leaders in Limoges during the Great War. The socialist mayor permitted workers to hold "private" meetings to express their opposition to the war. By arguing that these meetings were private he circumvented the ban on "public" antiwar protest meetings. At these gatherings the workers vented their opposition to the war and sustained their traditional antimilitarism. The sensitivity of the socialist leadership to the work- 
ing-class grass roots helps to explain why the majority of Limoges's workers remained loyal to the Socialist party after the war rather than deserting to the Communist party.

Judy Coffin (University of California, Riverside), in "Discussions of Women's Work in Late Nineteenth Century Paris: Production, Consumption and Sweated Labor," assessed the radical shift which occurred on these issues. Whereas during the 1860 s social critics such as Frédéric LePlay and Jules Simon believed women's work in the home was both moral and productive-a woman at home could work and watch over children at the same time-by 1900 a broad spectrum of observers felt homework was immoral and unproductive. Industrial work now seemed a panacea. Factory labor could teach valuable skills, a sense of organization, and discipline. Moreover, factories could be regulated to insure a healthy work environment, as opposed to the unsanitary condition in the tenements. Coffin then discussed the rise of women's consumer leagues. These turn-ofthe-century organizations argued that the power women lost in the home as producers they could regain in the marketplace as consumers. In future work, Coffin plans to pursue the interaction between the consumer leagues, the feminist and socialist movements, and the emerging welfare state.

Keith P. Luria (North Carolina State University) considered early modern Europe in his paper "Popular Culture: The Rise and Fall of a Concept." But his critique can be fruitfully applied to the concept of working-class culture. $\mathrm{He}$ argued that the dichotomy between elite and popular culture has led to a misplaced emphasis on classification rather than on the creation and appropriation of culture. The concepts of class and gender are much more fruitful and can provide a more nuanced cultural analysis than the broad dichotomy of "popular" and "elite." 